B1

\section{EVALUATION OF GEOPHYSICAL TECHNIQUES FOR DIATREME DELINEATION IN THE COLORADO- WYOMING KIMBERLITE PROVINCE}

\section{J.A. CARLSON, R.B.JOHNSON, M.E. MCCALLUM,}

\section{J.P.PADGET}

The Superior Oil Company, Fort Collins, Colorado 80524

Kimberlite diatremes in northern Colorado and southern wyoming are generally characterized by poor exposure due to truncation by erosion surfaces and presence of ubiquitous colluvial and(or) soil cover. Ground geophysical methods may be used in conjunction with geological mapping to delineate diatreme contacts. Magnetic surveys reveal that most diatremes are characterized by small positive dipolar anomalies. Convolution of magnetic data and removal of regional magnetic gradients allow for delineation of diatreme boundaries. Electrical resistivity and conductivity (electromagnetic) surveys show that kimberlitic soils are generally 5-10 times more conductive than granitic soils. The broadside EM method was effective for locating kimberlite contacts in areas of modest soil cover whereas kimberlite covered by as much as 25 meters of surficial material could be detected using the VLF method. Radioactivity surveys were effective only in areas where soil cover is thin to absent. Gravity and refraction seismic methods were ineffective in determining diatreme contacts because of a common lack of appreciable contrasts in density and elasticity of kimberlite and host granites. Magnetic, electrical resistivity, and electromagnetic methods clearly are the most effective geophysical techniques tested for delineating kimberlite contacts in the Colorado-Wyoming kimberlite province. (Study supported by grants from the Rocky Mountain Energy Company and the Geological Soc. of America)

\section{B2}

A TELEDETECTIVE STUDY OF KIMBERLITE REGIONS IN N. AMERICA, E. AFRICA, AND SIBERIA

THOMAS L. WOODZICK and M.E. MC CALLUM Dept. of Earth Resources, Colorado State University, Fort Collins, Colorado 80523

Teledetective evaluation involves the integrated use of remote sensing, geomorphological and geo- physical data planes to depict the surface and subsurface character of provinces that occur in extremely different environments. Study areas in Colorado-Wyoming, Tanzania and Yakutia were chosen on the basis of their diversity: e.g. elevation (2400m, 1200m, 300m, respectively), climate (temperate, equatorial, arctic), country rock (granite, granite, limestone), and floral cover (montane forest, grassland, taiga). Through the analysis of similarly scaled Landsat images (infrared reflectance), aeronautical maps (drainage patterns and topography), and geophysics (mass distribution and magnetic variation), the teledetective approach permits several related but distinct aspects of a given kimberlite province to be considered simultaneously and to be compared to other known or suspected kimberlite provinces, in terms of tectonic grain and specific textural and(or) structural features. The technique indicates that the ColoracoWyoming State Line Kimberlite District, the Mwadui region, and the Mir region all seem to be characterized by some type of cross-cutting textural signature where the regional trend is inter rupted or intersected by another trend. Pretorius (1981) suggests that diamondiferous kimberlites in southern Africa tend to occur at the intersection of extensive anteclisal concentric and radial patterns. Assuming that the textural interference patterns observed in this study also reflect deep-seated zones of structural disturbance (e.g. intersecting fault systems) that could provide conduits for the ascent of kimberlite magma, such features may have value in delineating favorable target areas in kimberlite exploration programs.

(Study supported by the Mining Research Center, Colorado School of Mines, Golden, Colorado)

\section{B3}

\section{GEOBOTANICAL EXPRESSION OF A BLIND KIM- BERLITE PIPE, CENTRAL INDIA}

\section{V.K. SHRIVASTAVA and P.O. ALEXANDER}

Department of Applied Geology, University of Saugar, SAGAR, 470003, M.P., India

Vegetation growing over a blind kimberlite pipe in central India was employed to explore the possibility of using it as an additional tool for searching hidden kimberlite pipes in areas indicated by geophysical prospecting. Hinota pipe $\left(24^{\circ} 39^{\prime} \mathrm{N}\right.$ : $\left.80^{\circ} 02^{\prime} \mathrm{E}\right)$ intrusive into the Precambrian quartz arenite is largly in an undisturbed state and is therefore an appropriate choice for this study.

Whereas the undergrowth over the quartzitic 
country rock is scanty, only about $10-20 \mathrm{~cm}$ high, it attains heights of $50-100 \mathrm{~cm}$ over the pipe area. Among the larger trees, the covered pipe supports not only more species but also a more luxuriant and healthy growth in contrast to the surrounding terrain. Among the 26 species recorded over the pipe area, Tectona grandis, Diospyres melanoxylon and Madhuca indica at tain a general height of $1 \overline{1.0,8.6}$ and 11.1 metres respectively in contrast to $7.6,5.6$ and 5.0 metres for the same species growing outside the pipe area. The positive geobotanical expression thus recorded is of such size and magnitude as to be apparent on air photographs. This is significant because geobotanical expression of ultrabasic rocks have generally been reported as 'conspicuously stunted and thinly developed', (Hawkes and Webb, 1962).

Detailed examination of plants on the pipe area also revealed effects of metal toxicities like chlorosis and white dead patches on leaves which obviously reflects higher $\mathrm{Cr}$ and $\mathrm{Ni}$ contents in soil over the pipe area in contrast to the country rock.

\section{B4}

\section{A REVIEW OF THE KIMBERLITIC ROCKS OF WEST-}

\section{ERN AUSTRALIA}

W.J. ATKINSON, F.E. HUGHES, C.B. SMITH

CRA Exploration Pty. Limited, Manager, Ashton Joint Venture, 21 Wynyard Street, Belmont, Western Australia 6104

In the course of exploration for diamond, CRA Exploration Pty. Lizited and the Astiton Joint Verture have discovered four diamond bearing kiseserlite provinces in western Australia. Three of these provinces are located targinal to the Kimberley Craton in the north of the state (Fig. 1), and one lies in the Carnarvon basin, adjacent to the Yilgarn Block, some $1300 \mathrm{~km}$ to the southwest.

The kigjerlites intrude rocks ranging in age from Lower Proterozoic to Permian, and are covered by sequences ranging in age from Cretaceous to Miocene.

The bodies range in size fro $=$ dyke-like features less than one metre in width

The bodies with larger surface area are volcanic crater deposits, champagneglass shaped in cross section, the narrow ster corresponding to the pipe epicr, The craters art infllied with air fall and water-deposited turfs and tremes was the emplacenent of massive, isneous-textured, magnatic kitberlite, $r$ ising to the surface in the shape of a lava-blister. This magmatic kimberlit fills the central part of the craters, and overlaps the tuffs towaros the margins.

Diamond content ranges frow trace amounts to econonic concentraticns. Fedsibility studies being carried out on the Argyle AKI kimberlite pipt are currenduction in 1985 , 2.25 million tonnes per annum operation, to come arte prothat limited comercial production from associated alluvial deposits will comence in the latter part of 1982 .

The exploration discoveries vere facilitated by early recognition that the petrography mineralogy and chemistry of the kimberlites varies from classical types resembling those of kimberley, South Africa, to unusual more highly fractionated, alkaline, silicic varieties having affinities with leucitelamproite and composec essentially of phenocrysts of oline \pm clinopyroxene \pm phlogopite + glassy groundmass. Mant le nodules recovered range from dunit to therzolite; graphic-textured intergrowths of picroilmenite and silica (after diopside?) occur at the Skerring pipe. Heavy mineral concentrates from the kimberlites yield pyrope, picroilmenite, chrome-diopside, chromite and zircon, the former two minerals being more abundant in the classical

Recognition of the characteristics of the unusual kimberlite/lamproite association strongly influenced exploration techniques, much use being made of such minerals as chromite, andradite and zircon as kimberlite indicator minerals during heavy mineral gravel sampling.

In regions where host rocks aisplayed a mild magnetic response it was found that the kimberlitic bodies produces recognisable magnetic anomalies from detaileó aeromagnetic surveys, and much use has been made of this technique in exploration.

\section{B5}

THE GEOLOGY OF THE MAYENG KIMBERLITE SILLS

D.B. APTER, F.J. HARPER and B.A. WYATT

Anglo American Research Laboratories, P O Box 106, Crown Mines, 2025, S.A.

The Mayeng Kimberlite Sills occur in the northern Cape province of South Africa,

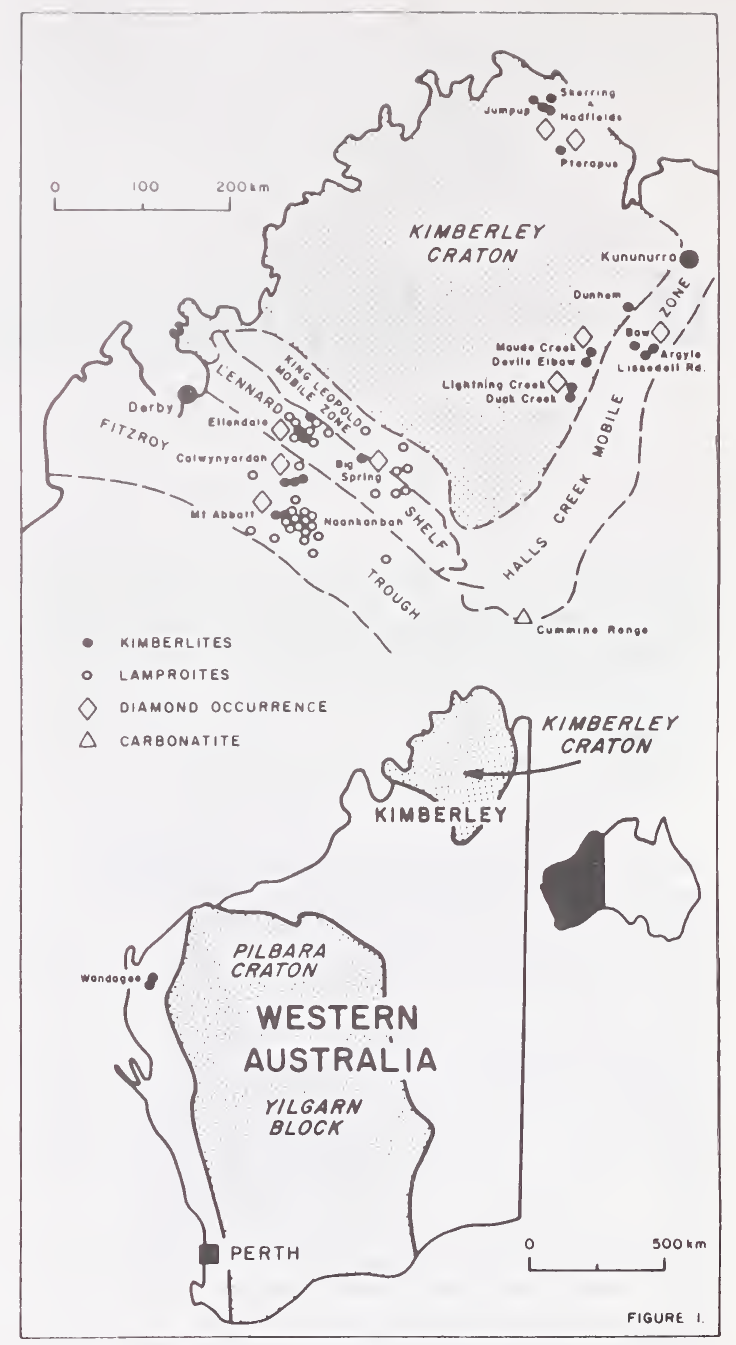

approximately $70 \mathrm{~km}$ north of Kimberley.

The sill complex was recently discovered by DBCM prospecting personnel, in an area where previously known kimberlites occur to the north and south. These sills are intruded into a massive but jointed andesitic horizon unconformably underlying the local Fcca shales. The Mayeng sills are different to other sill complexes in the Kimberley area, where instrusion into Ecca shales is probably controlled by the overlying Kimberley Dolerite Sheet. An extensive drilling program indicated that the sill complex comprises numerous sills, apparently lensoid in shape and occurring at irregular depths. This is due to intrusion into randomly spaced planes of weakness in the jointed host lava. Detailed drilling results outlined two main sill zones, one dominantly macroporphyritic, the other aphanitic. Throughout the sill complex, however, both textural types of kimberlite are found. The petrography, mineral chemistry and bulk rock

chemistries of the two main sill types have been examined in detail.

Despite the ohvious differences in texture, the kimberlite sills are 